SPORTIVE: Journal of Physical Education, Sport and Recreation
Volume 1 Nomor 1 September 2017
e-ISSN: 2597-7016 dan p-ISSN: $2595-4055$
@) (1) This work is licensed under a Creative Commons Attribution
4.0 International License

\title{
Kontribusi Power Tungkai, Kecepatan Lari, Dan Panjang Tungkai Terhadap Kemampuan Lompat Jauh Pada Siswa SMPN 2 Sabbangparu Kab.Wajo
}

\author{
Suwardi, Hikmad Hakim, Apriadi Jumaldi
}

\author{
Keywords : \\ Powet Tungkai; \\ Kecepatan Lari; \\ Panjang Tungkai; \\ kemampuan Lompat \\ jauh.

\section{Corespondensi Author \\ SMPN 2 Sabbangparu \\ Kab.Wajo \\ Email: \\ suwardi80@gmai.com}

\begin{abstract}
ABSTRAK
Jenis penelitian ini ialah penelitian deskriptif dengan menggunakan teknik analisis jalur (Path Analysis). Populasinya adalah seluruh siswa SMPN 2 Sabbangparu Kab. Wajo. Sedangkan populasi terjangkaunya adalah kelas VII dan VIII yang totalnya berjumlah 60 orang. Teknik penentuan sampelnya adalah $50 \%$ dari jumlah jumlah populasi • terjangkau yaitu 30 orang. Teknik analisa data yang digunakan adalah analisis statistik deskriptif dan analisis jalur dengan bantuan program computer SPSS 21 dengan taraf signifikan 95\% atau a $=0,05$. Hasil penelitian ini menunjukkan bahwa (1) Ada pengaruh langsung power tungkai terhadap panjang tungkai. sebesar 47,60\%.(2) Ada pengaruh langsung kecepatan lari terhadap panjang tungkai. sebesar 69,70\% . (3) Ada pengaruh langsung power tungkai terhadap kemampuan lompat jauh. sebesar $41,30 \%$. (4) Ada pengaruh langsung kecepatan lari terhadap kemampuan lompat jauh. sebesar 62,0\%. (5) Ada pengaruh langsung panjang tungkai terhadap kemampuan lompat jauh. sebesar $35,90 \%$. (6) Ada pengaruh power tungkai terhadap kemampuan lompat jauh melalui panjang tungkai. sebesar $41,30 \%$. (7) tidak terdapat pengaruh kecepatan lari terhadap kemampuan lompat jauh melalui panjang tungkai. Karena nilainya sebesar 17,10\% <0,620.
\end{abstract}

\section{PENDAHULUAN}

Pendidikan jasmani dan olahraga merupakan bagian integral dari pendidikan secara keseluruhan, yang bertujuan untuk mengembangkan aspek kebugaran jasmani, keterampilan gerak, keterampilan berfikir kritis, keterampilan sosial, penalaran, stabilitas emosional, tindakan moral, aspek pola hidup sehat dan pengenalan lingkungan bersih melalui aktifitas jasmani olahraga dan kesehatan yang direncanakan secara sistematis dalam rangka pencapaian tujuan pendidikan nasional.

Pendidikan jasmani dan olahraga
merupakan media untuk mendorong
pertumbuhan fisik, perkembangan psikis,
keterampilan motorik, pengetahuan dan
penalaran, penghayatan nilai-nilai (sikap-mental-
emosional-sportivitas-spritual-sosial), serta
pembiasaan pola hidup sehat yang bermuara
untuk merangsang pertumbuhan dan
perkembangan kualitas fisik dan psikis yang
seimbang. Pembelajaran pendidikan jasmani di
sekolah dasar menuntut guru untuk kreatif,
efektif dan menyenangkan dalam menyampaikan
materi untuk itu perlu adanya variasi dalam


pembelajaran karena sesuai dengan karakteristik murid.

Pendidikan jasmani merupakan suatu proses pembelajaran melalui aktifitas jasmani yang dirancang dan disusun secara sistematik untuk meningkatkan kesegaran jasmani. Mengembangkan keterampilan motorik, pengetahuan dan perilaku hidup sehat dan aktif, sikap sportif serta kecerdasan emosi. Dalam SK Menpora Nomor 053/A/MENPORA/1994, tentang pola Dasar Pembangunan Olahraga Nasional dikutip dari:

M. Anwar Pasau (2012:105) dinyatakan bahwa pendidikan jasmani adalah suatu proses pendidikan yang dilakukan secara sadar dan sistematis melalui berbagai kegiatan jasmani dalam rangka memperoleh kemampuan dan keterampilan jasmani, pertumbuhan fisik, kecerdasan,dan pembentukan watak.

Sedangkan Syarifuddin 1997 (dalam Andi Ihsan \&Hasmiyati, 2011:15) mengatakan sebagai berikut:pendidikan jasmani merupakan bagian integral dari pendidikan keseluruhan melalui berbagai aktifitas jasmani yang bertujuan mengembangkan individu secara organik, neumoskuler, intelektual, dan emosional.

Artinya, pendidikan jasmani tidak hanya mencakup pada aspek jasmani saja tetapi juga aspek kognitif, afektif dan psikomotor selain itu pendidikan jasmani juga mencakup aspek mental, emosional, sosial dan spritual.Salah satu masalah utama dalam pembelajaran Pendidikan jasmani ialah belum efektifnya pembelajaran di sekolah. Hal ini disebabkan beberapa faktor diantaranya terbatasnya sarana dan prasarana yang digunakan untuk mendukung proses pembelajaran Pendidikan jasmani.

Tujuan pendidikan jasmani dan olahraga yang utama yaitu ranah kognitif, afektif, dan psikomotor serta fisik selama ini sering terabaikan sehingga tujuan dalam rangka pelaksanaan pendidikan disekolah yang berperanan sangat penting adalah seorang guru, sebab gurulah yang secara langsung membina dan mengembangkan kemampuan siswa melalui proses pembelajaran yang dilakukan. Upaya pembinaan itulah yang dapat menentukan siswa menjadi cerdas, terampil dan bermoral tinggi seperti yang diharapkan bangsa pada generasi mudanya. Oleh karena itu sejumlah kemampuan guru tersebut hendaklah benar-benar diterapkan dalam rangka melaksanakan tugasnya disekolah dan diharapkan untuk itu semua guru pendidikan jasmani dan olahraga dituntut untuk bisa menguasai semua gerakan dan teknik dasar atletik.

Dari sekian macam aktivitas jasmani olahraga, atletik disebut sebagai "IBU" dari semua cabang olahraga, karena atletik terdiri dari gerakan-gerakan dinamis dan harmonis seperti jalan, lari, lompat, dan lempar. Itu semua menjadi aktivitas dasar dari semua cabang olahraga sehingga disebut induk dari dari semua cabang olahraga. Atletik merupakan mata pelajaran olahraga atau pendidikan jasmani yang wajib diberikan dari jenjang pendidikan dasar sampai jenjang pendidikan tinggi. Lari adalah nomor atletik yang menjadi dasar dan hampir semua cabang. Dengan atletik maka diharapkan adanya perbaikan dari aspek fisik menjadi meningkat, seperti: faktor kecepatan, daya tahan, kekuatan, keterampilan, dan kelincahan. Dan setelah aspek fisik terpenuhi, maka diharapkan tubuh memiliki kekebalan terhadap suatu penyakit dan juga meningkatkan mental anak didik seperti: rasa percaya diri, keberanian, kebersamaan, kejujuran, disiplin diri, dan lain-lain.

Melompat merupakan suatu bagian yang sangat penting dalam dunia gerak manusia. Anak-anak pada umumnya suka melompatlompat untuk menyatakan kegembiraannya dan kesukaannya untuk bergerak. Pada umumnya pula manusia itu mempunyai sifat ingin mempertinggi kecakapan dan ketangkasan yang lama kelamaan berubah menjadi pertandingan melawan sesamanya. Dengan jalan demikian, terciptalah pertandingan-pertandingan seperti yang dikenal sekarang yang salah satunya terdapat bagian yang disebut melompat. Agar dapat melakukan lompat jauh yang baik, diperlukan suatu teknik atau metode latihan yang tepat dan kondisi fisik agar menghasilkan prestasi yang baik. Hal ini sesuai dengan pendapat M.Sajoto (1995) bahwa "Kondisi fisik adalah satu prasyarat yang sangat diperlukan dalam usaha peningkatan prestasi seorang atlit bahkan dapat dikatakan sebagai keperluan dasar yang tidak dapat ditunda atau di tawar-tawar lagi". Kecepatan merupakan salah satu bagian dari teknik lompat jauh.

Kecepatan merupakan unsur dasar setelah kekuatan dan daya tahan yang berguna untuk mendukung pencapaian prestasi secara optimal. Karena, Semakin cepat kecepatan lari saat awalan akan didapatkan jarak yang maksimal dari lompatan tersebut. Hal ini 
menunjukkan bahwa jarak lompatan dipengaruhi oleh kecepatan lari pada saat awalan.

Pada pelaksanaan lompat jauh yang perlu menjadi perhatian serius adalah panjang tungkai karena memiliki peranan untuk mencapai lompatan jauh, makin panjang tungkai seseorang maka makin jauh pula lompatan yang dicapai. Oleh karena itu, selain panjang tungkai juga dibutuhkan unsur fisik lain yang dapat mendukung kemampuan lompatan, yaitu daya ledak (power). Daya ledak adalah kemampuan seseorang untuk mempergunakan kekuatan maksimal yang dikerahkan dalam waktu singkat. Dengan demikian power tungkai adalah kemampuan seseorang untuk melakukan atau mempergunakan kekuatan yang maksimal dan dengan waktu yang sangat singkat.

Dengan demikian apabila seorang atlet lompat jauh memiliki panjang tungkai dan daya ledak (power) tungkai maka kemampuan dan jarak lompatan akan bisa lebih baik. Namun hal ini belum terlihat pada siswa SMPN 2 SABBANGPARU Kab.Wajo, sehingga prestasi yang diharapkan belum tercapai.

Berdasarkan permasalahan di atas, maka dapat disimpulkan bahwa pencapaian prestasi lompat jauh dipengaruhi oleh beberapa aspek dan faktor-faktor dalam latihan. Maka dari itu penulis terdorong untuk meneliti "Kontribusi Power Tungkai, Kecepatan Lari, dan Panjang Tungkai Terhadap Kemampuan Lompat Jauh Pada Siswa SMPN 2 SABBANGPARU Kab.Wajo".

\section{METODE PENELITIAN}

Pada dasarnya metode merupakan teknik atau cara yang dipergunakan untuk mencari pembuktian secara ilmiah yang dilakukan secara sitematis dalam mengungkapkan dan memberi jawaban atas permasalahan yang dikemukakan dalam suatu penelitian, sehingga arah dan tujuan pengungkapan fakta atau kebenaran sesuai dengan apa yang ditemukan dalam penelitian dan betul-betul sesuai dengan tujuan yang diharapkan. Jenis penelitian yang dilaksanakan adalah jenis penelitian ex pos facto. Menurut Sudaryono (2013:11) dalam penelitiaan ex pos facto, peneliti menyelidiki permasalahan dengan mempelajari atau meninjau variable - ariabel. Variabel terikat dalam penelitian seperti ini segera dapat diamati dan persoalan utama peneliti selanjutnya adalah menemukan penyebab yang menimbulkan akibat tersebut.

Menurut Sugiyono (2011:61) mengungkapkan bahwa: "Populasi adalah wilayah generalisasi yang terdiri atas: obyek/subyek yang mempunyai kualitas dan karakteristik tertentu yang ditetapkan oleh peneliti untuk dipelajari dan kemudian ditarik kesimpulannya.

Berdasarkan pandangan beberapa pakar tersebut, maka populasi dalam penelitian ini adalah siswa SMPN 2 SABBANGPARU Kab.Wajo

Sugiyono (2011:62) mendefinisikan "Sampel adalah bagian dari jumlah karakteristik yang dimiliki oleh populasi”. Sedangkan menurut Winarno (2011:83) mengemukakan bahwa sampel adalah bagian dari populasi yang menjadi pusat penelitian kita, dalam ruang lingkup dan waktu yang kita tentukan.

Berdasarkan pengertian tersebut, maka sampel yang diambil atau digunakan dalam penelitian ini berjumlah 30 orang siswa SMPN 2 SABBANGPARU Kab.Wajo

\section{HASIL DAN PEMBAHASAN}

Hipotesis pertama yaitu ada kontribusi langsung Power Tungkai terhadap Panjang tungkai. Berdasarkan hasil uji hipotesis yang dilakukan, nilai signifikan yang diperoleh adalah 0,004 karena nilai signifikan lebih kecil dari 0,05 $(0,004<0,05)$ maka hipotesis yang diajukan diterima. Dengan kata lain Power Tungkai berkontribusi langsung terhadap Panjang tungkai. Hipotesis kedua yaitu ada kontribusi langsung Kecepatan lari terhadap Panjang tungkai. Berdasarkan hasil uji hipotesis yang dilakukan, nilai signifikan yang diperoleh adalah 0,000 karena nilai signifikan lebih kecil dari 0,05 $(0,000<0,05)$ maka hipotesis yang diajukan diterima. Dengan kata lain Kecepatan lari berkontribusi langsung terhadap Panjang tungkai. Dalam mempelajari berbagai kemampuan gerak yang baru, maka jelaslah harus mempunyai panjang tungkai yang baik. Selain itu, dengan seringnya melakukan aktivitas yang beragam dan melingkupi aspek olahraga yang dibutuhkan juga dapat membantu perkembangan dan pertumbuhan seseorang. Karena dengan banyaknya aktivitas gerak dapat membantu semakin aktifnya organ-organ dalam 
tubuh untuk bekerja. Dengan demikin berdampak pula terhadap peningkatan ukuran dan kemampuan dari bagian-bagian tubuh yang sering digerakkan. Kecepatan lari merupakan kunci yang menentukan fisiologis atlet dari performance dan yang penting adalah memeperbaiki tujuan dari program latihan. Oleh karena itu Kecepatan lari sangat erat kaitannya dengan Panjang tungkai.

Hipotesis ketiga yaitu ada kontribusi langsung Power Tungkai terhadap Kemampuan lompat jauh. Berdasarkan hasil uji hipotesis yang dilakukan, nilai signifikan yang diperoleh adalah 0,001 karena nilai signifikan lebih kecil dari 0,05 $(0,001<0,05)$ maka hipotesis yang diajukan diterima. Dengan kata lain, Power Tungkai berkontribusi langsung terhadap Kemampuan lompat jauh. Hal ini memberikan sumbangan kepada individu untuk dapat tampil di berbagai keterampilan motorik. Artinya bahwa untuk dapat melakukan aktivitas dengan baik harus ditunjang dengan Kemampuan lompat jauh yang baik pula. Power Tungkai kontribusinya dengan Kemampuan lompat jauh sangat berkontribusi dalam olahraga karena setiap orang yang mempunyai Power Tungkai yang ideal dan Kemampuan lompat jauh yang dimiliki bisa menunjang pada cabang olahraganya.

Hipotesis keempat yaitu ada kontribusi langsung Kecepatan lari terhadap Kemampuan lompat jauh. Berdasarkan hasil uji hipotesis yang dilakukan, nilai signifikan yang diperoleh adalah 0,000 karena nilai signifikan lebih kecil dari 0,05 $(0,000<0,05)$ maka hipotesis yang diajukan diterima. Dengan kata lain, Kecepatan lari berkontribusi langsung terhadap Kemampuan lompat jauh. Kecepatan lari merupakan kunci yang menentukan fisiologis atlet dari performance dan yang penting adalah memeperbaiki tujuan dari program latihan. Oleh karena itu Kecepatan lari sangat erat kaitannya dengan Kemampuan lompat jauh yang baik pula.

Hipotesis kelima yaitu ada kontribusi langsung Panjang tungkai terhadap Kemampuan lompat jauh. Berdasarkan hasil uji hipotesis yang dilakukan, nilai signifikan yang diperoleh adalah 0,007 karena nilai signifikan lebih kecil dari 0,05 $(0,007<0,05)$ maka hipotesis yang diajukan diterima. Dengan kata lain, Panjang tungkai berkontribusi langsung terhadap Kemampuan lompat jauh.

Hipotesis keenam yaitu ada kontribusi tidak langsung Power Tungkai melalui Panjang tungkai terhadap Kemampuan lompat jauh.
Berdasarkan hasil uji hipotesis yang dilakukan, nilai koefisien beta yang diperoleh adalah 0,171 . karena nilai koefisien beta yang diperoleh lebih kecil jika dibandingkan koefisien beta kontribusi langsung Power Tungkai terhadap Kemampuan lompat jauh yaitu $0,413(0,171<0,413)$ maka hipotesis yang diajukan ditolak. Ini berarti bahwa tidak terdapat kontribusi tidak langsung antara Power Tungkai melalui Panjang tungkai terhadap Kemampuan lompat jauh. Jika dihubungkan berdasarkan hipotesis ketiga dimana terdapat kontribusi langsung Power Tungkai terhadap Kemampuan lompat jauh, terdapat perubahan yang signifikan. Dimana jika turut dikontribusii oleh Panjang tungkai, maka tidak terdapat kontribusi tidak langsung yang signifikan. Hal ini berarti bahwa walaupun Power Tungkai tidak berkontribusi banyak terhadap Kemampuan lompat jauh jika Panjang tungkai ikut berkontribusi, maka tidak terdapat kontribusi tidak langsung antara Power Tungkai melalui Panjang tungkai terhadap Kemampuan lompat jauh. Kemampuan lompat jauh merupakan kemampuan yang mengharuskan seseorang mempunyai Power Tungkai yang ideal, kemampuan gerak, kemampuan fisik, kemampuan tehnik dan kemampuan mental yang baik. Sehingga jika seseorang memiliki Power Tungkai yang ideal maka seseorang berpotensi untuk mempunyai Kemampuan lompat jauh yang lebih baik pula.

Hipotesis ketujuh yaitu ada kontribusi tidak langsung antara Kecepatan lari melalui Struktur terhadap Kemampuan lompat jauh. Berdasarkan hasil uji hipotesis yang dilakukan, nilai koefisien beta yang diperoleh adalah 0,250. karena nilai koefisien beta yang diperoleh lebih kecil jika dibandingkan koefisien beta kontribusi langsung Kecepatan lari terhadap Kemampuan lompat jauh yaitu $0,620(0,250<0,620)$ maka hipotesis yang diajukan ditolak. Ini berarti bahwa tidak terdapat kontribusi tidak langsung antara Kecepatan lari melalui Panjang tungkai terhadap Kemampuan lompat jauh. Berdasarkan hipotesis keempat dimana terdapat kontribusi langsung yang signifikan Kecepatan lari terhadap Kemampuan lompat jauh. Jika seseorang memiliki Kecepatan lari yang baik, maka potensi untuk meningkatkan Kemampuan lompat jauh akan semakin besar karena Kecepatan lari sangat menentukan performance seseorang dalam melakukan teknik Kemampuan lompat jauh. 


\section{SIMPULAN DAN SARAN}

Bab ini memuat kesimpulan yang merupakan tujuan akhir dari suatu penelitian yang dijelaskan berdasarkan hasil analisis dan pembahasan. Dari kesimpulan penelitian ini akan dikemukakan beberapa saran dan rekomendasi bagi penelitian pengembangan hasil penelitian selanjutnya. 1) Ada kontribusi langsung yang signifikan antara Power Tungkai terhadap Kemampuan lompat jauh Siswa SMPN 2 Sabbangparu Kab.Wajo. 2) Ada kontribusi langsung yang signifikan antara Kecepatan lari terhadap Kemampuan lompat jauh Siswa SMPN 2 Sabbangparu Kab.Wajo. 3) Ada kontribusi langsung yang signifikan antara Power Tungkai terhadap Kemampuan lompat jauh Siswa SMPN 2 Sabbangparu Kab.Wajo. 4) Ada kontribusi langsung yang signifikan antara Kecepatan lari terhadap Kemampuan lompat jauh Siswa SMPN 2 Sabbangparu Kab.Wajo. 5) Ada kontribusi langsung yang signifikan antara Panjang tungkai terhadap Kemampuan lompat jauh Siswa SMPN 2 Sabbangparu Kab.Wajo.

Berdasarkan kesimpulan hasil penelitian yang telah dikemukakan di atas, maka diajukan beberapa saran sehubungan dengan upaya meningkatkan pengetahuan tentang lompat jauh. 1) Pelatih dan Pembina olahraga, agar di dalam memilih atlet lompat jauh yang ingin dikembangkan harus memperhatikan unsur panjang tungkai dan daya ledak otot tungkai sebagai penunjang dalam melakukan lompatan. 2) Bagi atlet, untuk meraih prestasi yang baik dalam lompat jauh memerlukan kerja keras dan latihan yang kontinyu dan berkaitan dengan teknik dasar lompat jauh. ilmu yang berguna sebagai bahan masukan.

\section{DAFTAR RUJUKAN}

Amari. 2012. Pembinaan kondisi fisik. Padang : Fakultas Ilmu Keolahragaan UNP.

Aminuddin. 2010. Atletik dan tekniknya. Jakarta : Perpustakaan Nasional

Ateng Abdu lkadir. 1992. Azas dan landasan Pendidikan Jasmani. Jakarta: Dirjen Dikti
Engkos Kosasih. 1985. Olahraga tehnik dan Program Latihan. Jakarta: Depdikbud Dirjen Dikti.

Hasmiyati \& Ihsan, A. 2011.Manajemen Pendidikan jasmani Olahraga dan Kesehatan.Makassar: Badan Penerbit UNM.

Harsono. 1988. Coaching dan Aspek-aspek Psikologis Olahraga Dalam Coaching. Jakarta : Dekdikbud, Dirjen Dikti.

1986. Ilmu Coachcing .Jakarta : Pusat Ilmu Olahraga KONI Pusat

I Gusti Ngurah Nala. 2011. Prinsip Pelatihan Fisik Olahraga. Denpasar : Udayana University Press.

Jarver Jess. 2013. Belajar dan Berlatih Atletik. Bandung : Pionir Jaya

Johnson, Barry L., and Jack K. Nelson,1986. Practical Measurements forevaluation physical Education. New York: Macmillan.

Jonath, Haag and Krempel, 1987 Bugar Dengan Latihan Beban. Jakarta: PT. Raja Grafindo Persada

Kurnia. N, Asep. (2004). Pendidikan Jasmani, Olahraga dan Kesehatan. Grafindo Media Pratama.

Munasifah. 2008. Lompat. Semarang : Aneka Ilmu

M. Sajoto. 1988.Pembinaan Kondisi Fisik Dalam Olahraga. Semarang : FPOK

1995. Pembinaan Kondisi Fisik dalam Bidang Olahraga. Jakarta: Depdikbud Dirjen Dikti.

Nur Ichsan Halim. 2011. Tes dan Pengukuran Kesegaran Jasmani. Makassar : Badan Penerbit UNM.

Pasau M. Anwar. 2012. Pertumbuhan dan Perkembangan Fisik Pendidikan Jasmani, Olahraga dan Kesehatan. Makassar : Badan Penerbit UNM 
Ramli. 2015. Dasar-Dasar Kepelatihan. Makassar: UNM

Santosa, Teguh., Wisahati, Aan Sunjata. 2010. Pendidikan Jasmani olahraga dan Kesehatan. Jakarta : Kemendiknas

Sudaryono, Gaguk Margono, Wardani Rahayu. 2013. Pengembangan Instrumen Penelitian Pendidikan. Jakarta : Graha Ilmu.

Sugiyono. 2015. Metode Penelitian Pendidikan. Bandung: Alfanbeta.

Suharno. HP. 1998. Ilmu Kepelatihan Olahraga. Yogyakarta: IKIP Yogyakarta Press.

Syaifuddin Aip dan Muhadi. 1992/1993. Pendidikan Jasmani dan Kesehatan. Jakarta: Depdikbud Dirjen Dikti.

Watson R, 1984., Athletic Ability ; The Anatomy of Winning, New York Wolfe Medical Publishing Ltd.

Winarno. 2011. Metodologi Penelitian Dalam Pendidikan Jasmani. Malang: Media Cakrawala Utama Prres.

Yudha M. Saputra. 2001. Dasar-dasar Ketrampilan Atletik. Jakarta: Departemen Pendidikan Nasional.

Yusuf Adisasmita. 1992. Olahraga Pilihan Atletik. Jakarta : Depdikbud Dirjen Dikti.

Zafar, Dikdik Sidik. 2010. Mengajar dan Melatih Atletik.Bandung: Remaja Rosdakarya 